\title{
How US newspapers view the UK's NHS: a study in international lesson-drawing
}

\author{
Sean Tunney ${ }^{1} \cdot$ Jane Thomas $^{2} \cdot$ Adam Cox $^{1}$
}

Accepted: 18 March 2021 / Published online: 25 April 2021

(c) The Author(s), under exclusive licence to Springer Nature Limited 2021

\begin{abstract}
Healthcare on both sides of the Atlantic is a highly charged political and economic subject. This work considers US media coverage of the UK's National Health Service (NHS), an under-researched area. We assess the framing of the NHS in editorials, opinion and feature articles during the time of the Obama administration to show how media can perform the role of lesson-drawing, a theory adopted from public policy research. The study also applies the notion of journalistic habitus in this context. Using these ideas, we address a hypothesis which holds that US coverage is framed around the flaws of the UK's NHS. The paper considers how intermedia editorial and news values operate, with commentators drawing a range of negative lessons in both the Democrat- and Republican-supporting press. We find that the NHS was often posited as a flawed international variant of the single-payer model, where newspapers employed an ahistoric explanation of failure and decline.
\end{abstract}

Keywords US newspapers · NHS · Lesson-drawing $\cdot$ Health journalism · Editorials · Opinion

\section{Introduction}

In February 2018, President Donald Trump, after learning of a protest over cuts in NHS funding, wrote on Twitter: 'The Democrats are pushing for universal health care while thousands of people are marching in the U.K. because their system is going broke and

Jane Thomas

J.L.Thomas@brighton.ac.uk

Sean Tunney

s.tunney@ roehampton.ac.uk

Adam Cox

adam.cox@ roehampton.ac.uk

1 University of Roehampton, Roehampton Lane, London SW15 5PH, UK

2 University of Brighton, Village Way, Falmer BN1 9PH, UK 
not working.' Pushback came from a seemingly unlikely source, the UK's Conservative health minister, who said that he was proud of the NHS 'where all get care no matter the size of their bank balance' (Dyer 2018).

The response from the minister was understandable in terms of his domestic audience, however. Polling showed Trump was disliked in the UK and there were concerns that the ever-popular NHS could become part of a post-Brexit US trade deal (Neville 2019). But Trump's initial salvo was significant. The US and the UK have historically enjoyed a 'special relationship' (Xu 2017). And, at the time, they were both led by right-wing governments. Why, in these circumstances, would an American president focus on the supposed policy failures of a close and ideologically aligned ally? The episode introduces us to the idea of lesson-drawing, a theory within public policy research, whereby officials study developments in other systems in order to evaluate their applicability, both positively (Nutley et al. 2012, p. 194) and negatively. So, 'policy leaders in a borrower country may distort the original meaning of [a] policy or programme for purposes of self-interest or in order to justify a pre-determined solution' (Park et al. 2014, p. 401). In this case, Trump's own rudimentary negative lesson-drawing came amid growing political momentum in the US for a single-payer approach to healthcare (Draper 2019).

Even after Joe Biden's election to the presidency in 2020, the prospects for US healthcare appear to be fraught with political contestation (Haeder 2020). Healthcare was a key issue in the 2020 presidential election (Kirzinger et al. 2020). And policy differences were further magnified by the COVID-19 pandemic (Cashin and El-Sayed 2020). During the Trump era, repeated efforts by the Republican Party to water down healthcare legislation guaranteed that it remained in the spotlight. Meanwhile, for Democrats over the same period, divisions on future healthcare reforms and approaches to the single-payer policy endured (Goodnough 2019). Nevertheless, by 2020, one survey found more Americans supported a single government coverage programme (Jones 2020).

What specifically prompted Trump's exchange on the NHS has further relevance for our purposes. He followed up his tweet on the NHS by thanking Fox News for 'exposing the truth' (Yeginsu 2018). The network's transatlantic reporting raises a question about how much other US media are involved in a similar process of drawing lessons from the UK to address stateside health policy. In assessing US coverage, we consider a seldom-asked question-how international lesson-drawing can be applied to media analysis. We discuss US newspapers' opinion and feature-length coverage to consider how the NHS was framed during battles over the Affordable Care Act 2010 (The Patient Protection and Affordable Care Act), which was dubbed 'Obamacare', during Barack Obama's presidency, from 2009 to 2017. We assess how journalistic rituals and habitus, alongside intermedia editorial and news values, operate in this context. 


\section{Literature review}

\section{Lesson-drawing, news values and social theory}

Rudolf Klein claims US policymakers have drawn lessons from the NHS, which have been "invoked to provoke horror at the very idea of "socialized medicine", (1997, pp. 1270-1271). Nevertheless, previous research has pinpointed the 'limited empirical or theoretical attention' to decision makers' negative lessondrawing across social science (Illical and Harrison 2007). In tandem, Tim Bale finds that 'political scientists have paid scant attention' to lesson-drawing 'within media discourse on politics' (2005, p. 387). Meanwhile, one influential survey by Diane Stone (1999) reports that journalists do undertake what was later described by theorists as 'policy borrowing' (Davis et al. 2018; Takayama et al. 2013; Saraisky 2015). Yet, these writers do not directly engage with lesson-drawing theory.

Nevertheless, Bale suggests a hypothesis could be 'profitably tested' concerning the extent to which media in one country might interpret the politics of another in such a way as to influence its domestic policy debates. 'In the conservative, business-friendly press this will mean exposing the flaws of supposedly recalcitrant [domestic] centre-left governments and parties and extolling the virtues of those that have, so to speak, "seen the light"' (2005, pp. 387, 400). Our work seeks to test an alternative variant of this premise, introducing intermedia analysis.

The research forms and tests a hypothesis that US health-related commentary and editorials concerning the NHS have framed coverage mainly around the flaws of the UK healthcare system and drawn negative lessons (H1). We shall explore the extent to which this was a particular feature of the business press, given debates about how such journalism might prioritise an 'investor perspective' over adherence to a 'fourth estate' ideal (Tambini 2010; Butterick 2015).

The framing of international themes in domestic health coverage highlights the significance of journalists' conceptions of newsworthiness and the interpretive decisions they make to select, emphasise and elaborate, as well as to exclude, in order to simplify 'reality' and grab attention (Entman 1993). Reflected on here is the extent to which leader and opinion writers adhere to the news values of negativity, novelty and proximity. Analysts of news have used various terms to refer to the first two, including conflict, drama and 'bad news' for the first, and unusualness, oddity and sensationalism for the second. What often links the two terms is that they represent a disruption of normal events (Caple and Bednarek 2013). And the focus on negative and sensational news can be at the expense of evidence and long-term statistics (van der Meer et al. 2019).

The third news value variously refers to the geographical proximity of the international comparator, its status and the extent to which news outlets' domestic audiences identify with the overseas community or have 'cultural proximity'. Theorists have considered cultural proximity as slippery, subjective and difficult to articulate (Bednarek and Caple 2012; Boesman et al. 2017). Yet, borrowing 
from international relations theory, Kim Nossal suggests that, 'stripped of its "clash of civilizations" baggage' a notion of 'kin-countries' could be apposite for countries such as the US and Britain (2018, pp. 62-75).

While news values are often considered when seeking to understand decisions on what gets covered and how extensively, less analysed are the criteria for newspaper editorial and opinion selection (Firmstone 2008, 2019; Marques and Mont'Alverne 2019). Francisco Marques and Camila Mont'Alverne (2019) identify yardsticks that go beyond news values to assess 'editorial-worthiness', which indeed not only include proximity and geographic reach, but also conflict and access to sources.

News values can also be analysed using the notion of 'habitus'. This 'system of schemes of perception and appreciation of practices, cognitive and evaluative structures which are acquired through the lasting experience of a social position', it is argued, structures journalists' strategies and practices (Zeng 2018). While 'field theory' illuminates interrelationships within news organisations and how current affairs actors are situated and interrelate in the broader 'field of power' (Stones 2015; Schultz 2007). These aspects of Pierre Bourdieu's social theory framework have been considered in relation to reporting, but, it appears, less so for editorial and commentary, where lesson-drawing can be more explicit.

Yuan Zeng's research on foreign correspondents-operating as 'sense makers of the distant "others", (2018, p. 1) —can help us consider how domestic health commentators perceive cultural proximity in editorial selection and draw international lessons. She describes how journalists are positioned in the field of Chinese correspondence, with differing relationships to the domestic habitus. News organisations, she suggests, encourage and value some for their strong journalist habitus, although they may lack local knowledge, connections and understanding of the 'Chinese mind'. Ida Shultz (2007) also takes from Bourdieu that newsworthiness is partly attributed according to the hierarchical position of the person judging. So might it be seen for those determining editorial worthiness on the editorial and opinion desks, where their role is regarded typically as a badge of seniority (Firmstone 2019, pp. 3, 16; Duff 2008, p. 232).

Monika Krause (2011) situates US media ownership within field theory, seeing journalism as dependent on a broader field of regulatory structures and cultural production, stretching beyond ownership. At the same time, she emphasises the role of journalistic practice itself as an indicator of autonomy. Furthermore, we can add, the seniority of columnists is related to their level of relative autonomy. That commentators can be syndicated, rather than necessarily write for a single title, is another factor in the power relations (Duff 2008, p. 240).

Reference to journalistic autonomy, of course, points to an age-old debate, which can be only touched on here, concerning the influence of owners over their papers and, consequently, their role on the US political stage. Aside from the methodological issues of measuring the influence of media owners beyond anecdote (Chomsky 2006), liberal pluralists, in particular, have pointed to control by readers, via the market, where the press reflects their political views (Tunney 2007). In riposte, others have directed attention to the dominant figure of Rupert Murdoch, albeit as an outlier, using News Corporation's titles as a vehicle for columnists and leader writers who share his particular conservative outlook (McKnight 2010, 2012). Of 
the newer takeovers, our sample includes The Wall Street Journal, which News Corp acquired in 2007. This acquisition was closely followed by an industry-wide crash, accelerated by the 2008 financial crisis, leaving investment firms as the largest owners (Soloski 2019; Pickard 2020). These companies focused on the bottom line, rather than content, making the market king. But 'Billionaire Savior' owners also returned (Wagner and Collins 2014, p. 768), 'buying newspapers to advance their political views' or promote their other business interests (Soloski 2019).

\section{The NHS and universal healthcare}

A reason for considering the NHS in a US context is that it offers a longstanding model of universal healthcare. The population is covered, regardless of employment and ability to pay. US proposals for universal provision have a history stretching back to at least 1912. Attempts at reform supported by Truman and Clinton were thwarted (Gusmano 2012, pp. 199-200; Oberlander 2003). Obama's extended insurance system was signed into law in 2010.

It is important here to define our terms. Universal healthcare is one where 'citizens can receive health care services without suffering financial hardships' (Myers 2017, p. 16). Daphne Myers (2017) defines three main types of universal system: an insurance mandate, where the government requires all are covered; two tier, where the state offers a basic provision, while allowing additional care to be purchased; and single payer. Obamacare's goal was to enable all residents to obtain either public or private health insurance, making it more like Western European universal social insurer systems than the NHS (Mariner 2014).

There is no consensus about the term 'single-payer' (Liu and Brook 2017; Glied 2009), although Sherry Glied (2009) provides a typology of it based on how concentrated revenue sources are, the level of subnational financing and the extent to which private insurance is involved. As the UK government directly finances the NHS and does not involve private insurance, it is classed as 'more single-payer orientated'. Providing universal coverage does not require this extent of 'single-payerness' (Glied 2009). Geographical and cultural proximity could well make Canada US journalism's international 'go-to' example of a single-payer system in terms of news values and lesson-drawing (Liu and Brook 2017; Hockett 2010). Yet the notion of kin-countries also affords relevance to coverage of UK healthcare. And UK state control over the NHS could offer stateside newspapers the editorial value of conflict.

Thus, arising from this, the primary research question that will inform our analysis is:

RQ1: To what extent did US press opinion present the NHS as emblematic of a single-payer system and use it to draw negative lessons?

To address RQ1, we will explore the extent to which coverage was framed around five themes: rationing, waiting times, care quality, expenditure and cost control. In particular, the discussion of 'death panels' features here (Desai et al. 2010). Sarah Palin coined the emotive phrase in August 2009. She railed against Obama's 'bureaucrats' deciding who was 'worthy of health care' (Meirick 2013; Begley 
2009; Callahan 2011). PolitiFact later judged the accusation 'Lie of the Year'. But polling indicated 'the death panel misperception remained' (Meirick 2013).

Some UK experts claim the existence of NHS 'death panels' 'can easily be dismissed' (Desai et al. 2010). However, the NHS does put in place medical care restrictions, following the advice of the National Institute for Health and Care Excellence (NICE) (Callahan 2011). Adhering to the conventions for news selection, NICE's rationing role makes it newsworthy and open to emotive UK reporting (Wilson et al. 2008). Addressing these issues, we shall consider this question:

RQ2: To what extent was the coverage of the NHS in the US press framed by rationing, waiting times, 'death panels', care and costs?

\section{Methodology}

To consider the hypothesis and related questions, this paper analyses editorials, opinion and features in the United States press that refer to the NHS. Editorials provide the institutional voice of newspapers, while opinion often offers an unofficial extension of a title's predominant ideology or an oppositional viewpoint (Firmstone 2019). Together, therefore, editorials, features and commentaries focus particularly on policies being advocated. This article undertakes both quantitative and qualitative content analysis (Hansen and Machin 2013; Mayring 2014) of a sample that included press from across the US during Obama's presidency, from January 20, 2009 to January 20, 2017.

We included the top 100 newspapers by circulation during the time period from the media monitoring service Burrelles' list of all United States newspapers (BurrellesLuce 2013), subject to availability on the Nexis database. To consider their support for political parties, we identified the papers' presidential endorsements prior to the 2008 election (Veltman 2016) (see Table 1). As the complete and full articles of the Los Angeles Times and The Wall Street Journal were not included there, we accessed the latter separately via the ProQuest archive. The search terms were National Health Service, NHS, UK, Brit* and Eng*, with and without relevant full stops. Given that syndicated articles were published to be read by different geographical audiences, they were counted as many times as they appeared.

The search generated 1,793 articles, including news stories and duplicates. (By comparison, there were 3,011 in the same period referring to either 'Canada' or 'Canadian' and also its form of healthcare, 'Medicare'.) Given the topic of our study, we included only leaders, commentary and features providing US audiences with insights into the NHS, including its role, structure or financing. This left us with a final sample of 290 pieces, composed of 174 columns, 86 editorials and 30 features (see Table 1).

Frame analysis was used to identify those decisions columnists, and feature and leader writers make to order 'reality'. Robert Entman (1993) sees the role of framing as a means of identifying what 'aspects of a perceived reality' writers have chosen to focus on. The more limited aim here was to both read and code articles in order to categorise them. Coding was undertaken for the quantitative content analysis to test the hypothesis that the commentary and editorials have drawn negative lessons. 
We identified articles' attitudes to the NHS and whether lesson-drawing took place, either explicitly or implicitly (Stone1999). To do this, we assessed if the articles either stated that US healthcare could learn from the NHS or referred to UK healthcare in a way that this might be implied, for instance in pointing to the 'dismal treatment of patients under Britain's National Health Service' (Anon 2010c), to take a negative example. We also coded on whether the NHS was treated as an emblematic type of healthcare system, such as single payer. And, following that, we identified a mutually exclusive primary frame relevant to the themes contained in RQ2 (Boykoff 2008, p. 555). We also identified those where none of the five thematic frames was present, revising the categories so they were both mutually exclusive and at a level of abstraction agreed as adequate to the subject matter. Two researchers separately coded 10 per cent of the sample and agreed on the categorisation. We recorded 99.3\% agreement, with a Scott's Pi average of 0.89 (Freelon 2010) and resolved the coding differences between us. The remaining sample was jointly coded.

Following the quantitative content analysis, further qualitative analysis was conducted to illuminate the data. This involved identifying salient textual illustrations, analogous to the 'anchor examples' in Philipp Mayring's explanation of what he describes as 'narrow qualitative content analysis'. Mayring defines these as 'prototypical text passages' within texts. They are relevant extracts, identified in order to describe or explain, exemplify or help itemise the thematic categories (Mayring 2014 , pp. 88-94, 95, 97). If any extracts were in any way atypical, they were identified as such and were placed as notes.

\section{Findings}

\section{Emblematic of a single-payer system}

Our first insight was the extent to which the articles drew negative lessons for the United States from the NHS model. Only 6\%, in columns and features, extracted positive lessons (17), while 55 leaders and 61 columns and features (40\% of the sample) advised readers to avoid the UK system. Not one editorial throughout the sample shone a positive light on the NHS. A majority of the newspaper titles that ran relevant material (11), including two Democrat candidate-endorsing newspapers, counselled against the NHS (Table 1). In the overall sample, over three times as many were generally hostile to the UK system (67 leaders and 64 columns and features, $45 \%$ ), than were positive (36 columns and features, 12\%). A total of 112 articles were neutral (39\%), with 11 (4\%) displaying mixed views.

One conservative business title stands out for how often it presented the NHS as a flawed model that US policymakers should avoid. In the Investor's Business Daily (which printed weekly from 2016, while continuing to publish daily online), 47 out of $49(96 \%)$ of the sampled articles delivered a transatlantic health warning. A number of pieces highlighted negative UK news developments, presenting them as the norm (see Table 1), stirring up the fear in some that if Democrats get their way, this country will rush to adopt a system much like the one that is killing people in Great Britain' (Anon 2010a). So, one editorial referred to the death toll at 


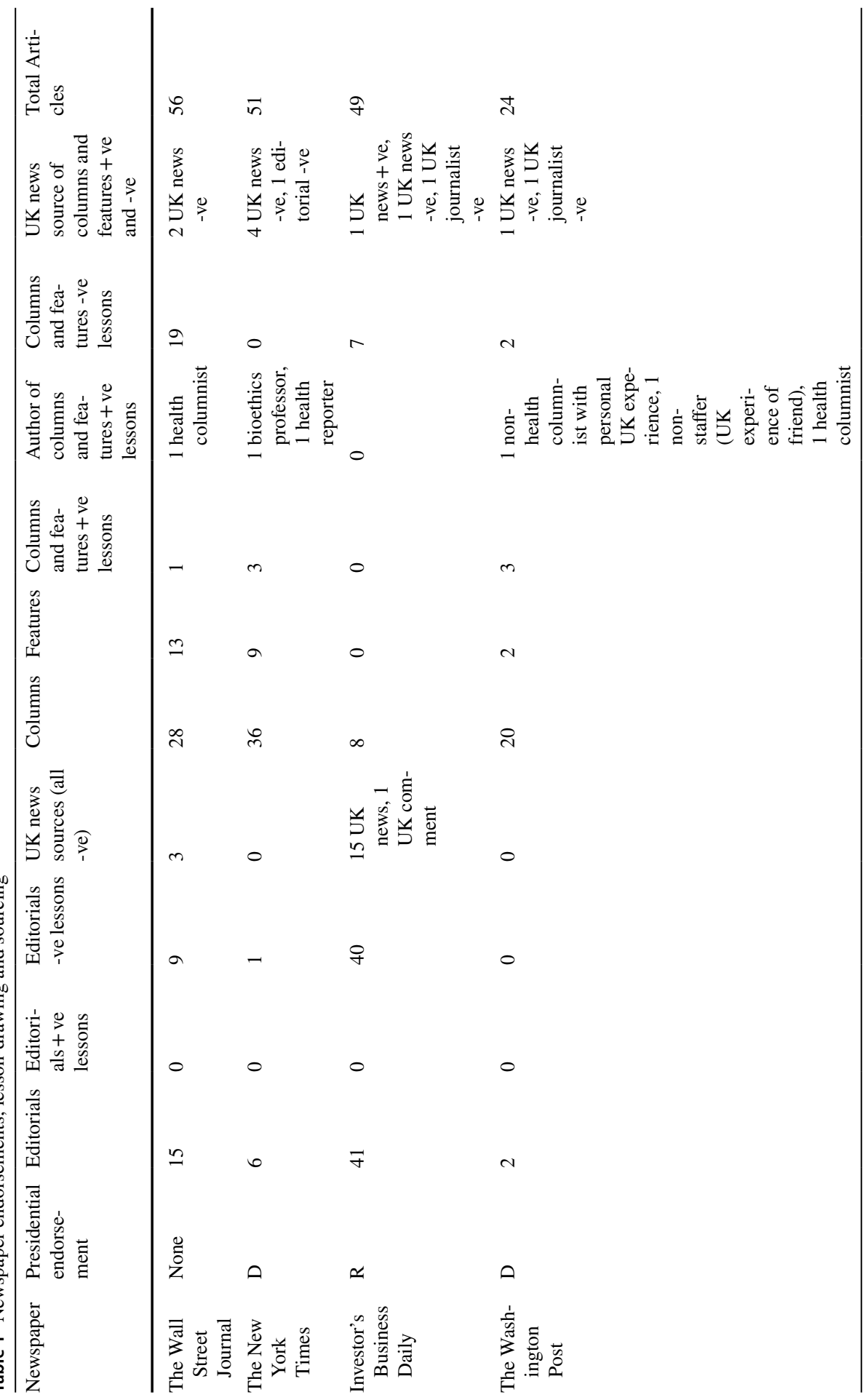

s. 


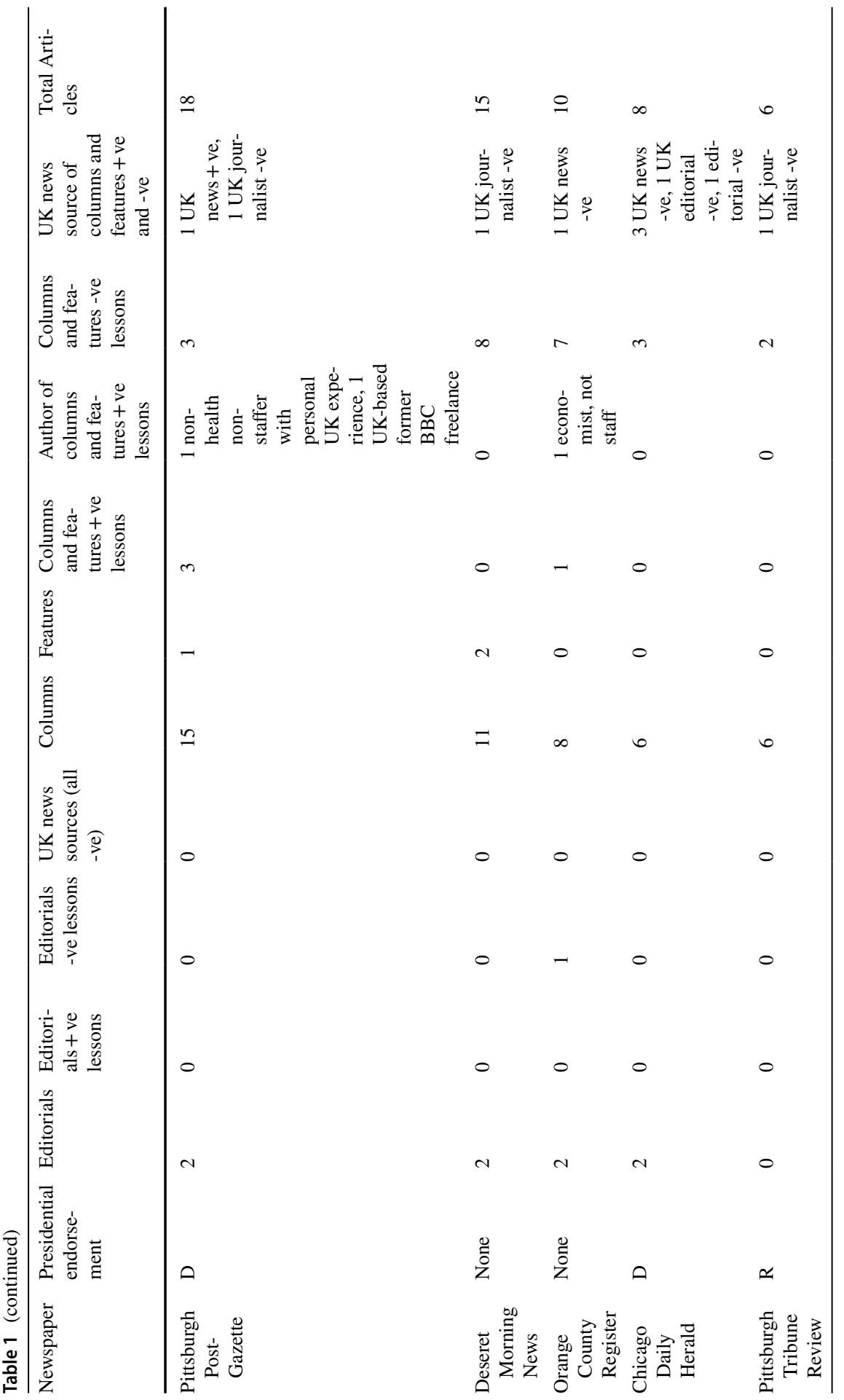




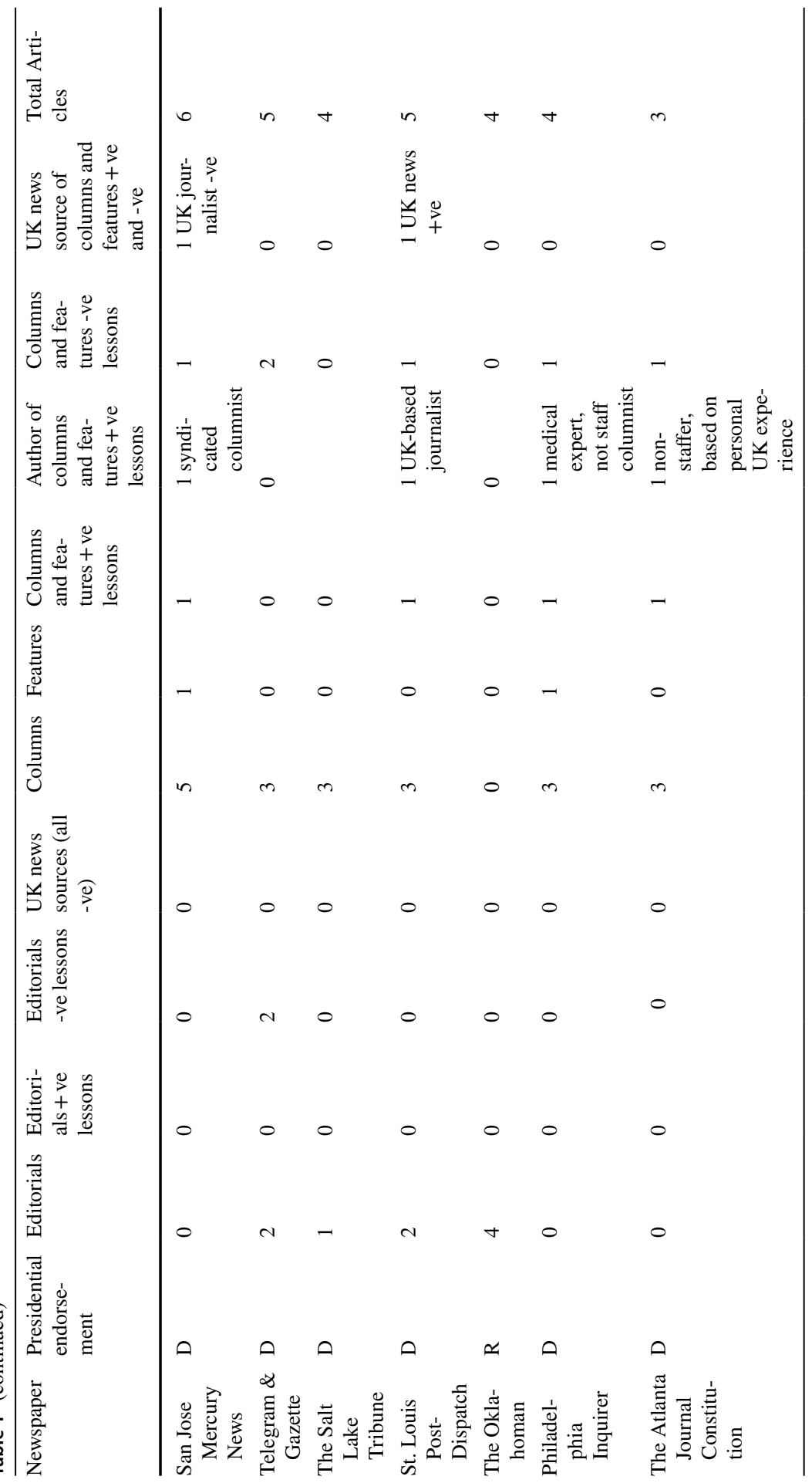

s. 


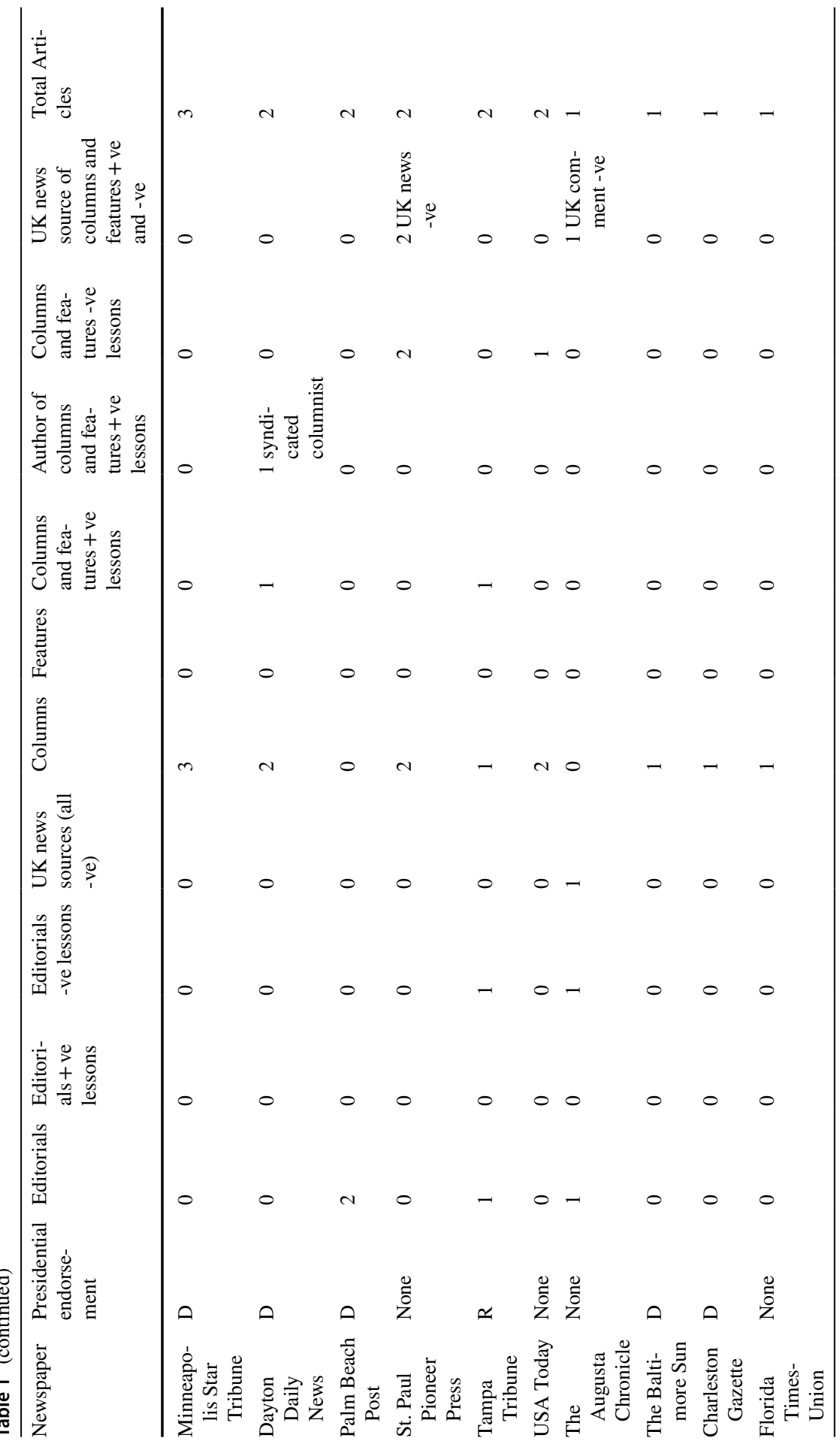




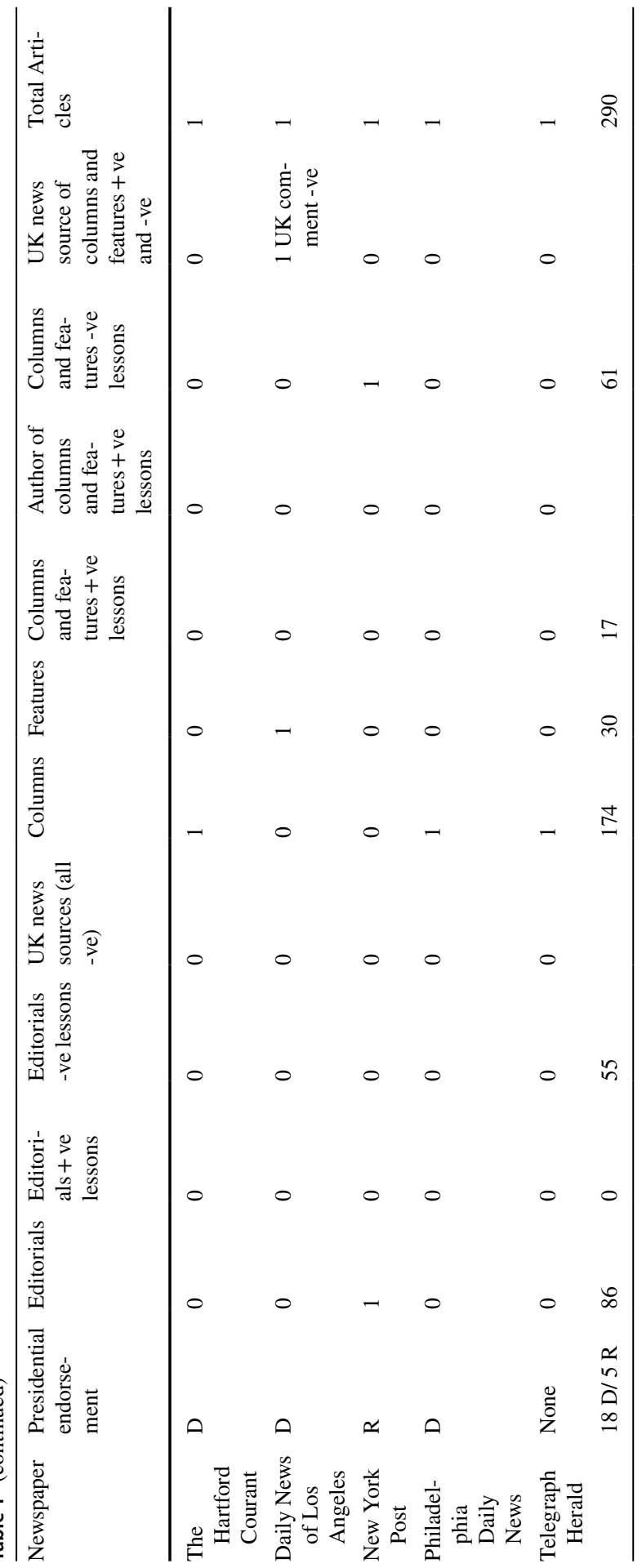

s. 
a Staffordshire hospital. This scandal, newsworthy because its negative care set it apart, was portrayed as emblematic of a system where '[r]ationing, misery, deathall are characteristic of Britain's health care' (Anon 2013a). More famously, one editorial claimed Stephen Hawking, who lived for 55 years with motor neurone disease under NHS care, 'wouldn't have a chance' under the UK system. It would regard his life as 'essentially worthless' (Anon 2009a). Also weighted negatively was the Republican-leaning Wall Street Journal (Archer and Clinton 2018), the title which covered the NHS the most. Half (28) of the articles sampled in the business title opposed in some way appropriating from the NHS, while one drew a positive lesson.

Forty-two articles overall referred to the NHS model as a single-payer system, with more than $70 \%$ (30) of those doing so in explicitly negative terms. Over half of these negative pieces (16/30) were in the two conservative business publications. The term 'socialized' - an adjective often used in a US context to denounce healthcare reform-appeared in $17 \%$ of the sample. The majority of those instances came from the two business titles. Two columns and two editorials characterised the NHS as a socialist system. One editorial dubbed it communist and another two labelled it drac.onian. ${ }^{1}$

\section{Framing: rationing, waiting times, 'death panels' and care}

A sizeable part of the journalism captured here referred to the NHS, but either was not framed around it or UK healthcare, or was neutral $(153,53 \%)$. The largest single number of health-focused pieces in the sample was framed around US domestic health issues $(53,18 \%)$. Obamacare was framed more negatively $(32,11 \%)$ than positively $(7,2 \%)$.

NHS rationing did frame coverage $(36,12 \%)$. While five columnists questioned whether rationing was such an issue for UK healthcare and one compared it positively with US insurance, more focused on the problems of rationing and waiting lists. These were the key frames of 12 editorials and six columns (6\%). Seven editorials and one column (3\%) were explicitly framed around the idea that rationing was killing UK patients. All but one were published in the conservative business titles, with their implied investor readerships (Hallin et al. 2013). Some of these focused particularly on waiting times, including at accident and emergency departments or for cancer treatment, and identified the NHS's problem as overuse.

In addition, while two articles offered a positive framing of NICE and one column was neutral, more framed it negatively. Five editorials and four columns (3\%) adopted this view, with a majority (six) in the two business titles. The Investor's Business Daily regularly embraced the 'death panel' portrayal, employing the pithy phrase to headline a range of NHS maladies. Others derided NICE as an Orwellian moniker, which 'literally decides matters of life and death' (Anon 2010b), sourcing

\footnotetext{
1 One conservative columnist syndicated in a Democrat-endorsing title pushed the hyperbole further. His article framing the NHS as socialized, rapidly became 'national socialist'. He warned 'the philosophy behind the horrors...' Hitler 'unleashed can be found in the beliefs of some of those who would use the power of the state to determine who gets help and who doesn't' (Thomas, 2009).
} 
UK press reports where NICE was described as denying care. Two other columns were framed around the view that rationing by price, i.e. excluding those who were uninsured, was preferable to using a body such as NICE. The poor quality of the NHS was the dominant frame for another 18 articles (6\%), with three specifically focusing on cancer care. Another three advocated privatisation to improve care, while two others focused on NHS staff leaving their professions.

\section{Framing: costs and convictions}

In contrast to the focus on rationing and care, few articles were framed around the costs of the NHS, either to the individual or to the taxpayer. Three columnists framed UK healthcare as costing less overall than its American counterpart. Four more (1\%) recognised that a service free at the point of use costs far less to individuals than US healthcare. Only one of these seven was in the business publications or the financial pages. Only one article was framed by the need for cost cutting, the dominant UK right-of-centre austerity narrative. Some four pieces referred to but were not framed around NHS waste and inefficiency, as part of a bureaucratic behemoth, with the '[s]kyrocketing costs...' marking 'government-controlled medical care systems' (Sowell 2009). Two referred to NHS spending expanding.

What is striking is the disconnect between what stateside writers identified as the consistent failures of the NHS and how they described 'Brits' (public, staff and politicians) as 'loving' the NHS - treating it as the 'closest thing ... to a religion' (Castle 2016). UK support for the NHS was the dominant frame of five columns and features, along with two editorials $(2 \%)$. Three more were framed positively around the NHS by the columnists themselves (1\%).

Among the larger number broadly advocating policy transfer from the NHS to the US were either writers describing personal experience of NHS care, outside experts or those whose beat was not health (Table 1). One Washington Post columnist, seriously injured while in the UK, concluded that 'as visions of those U.S. health-care dollars spiraled upward in my head, I realized how fortunate I was to have received the care that Britain provides for all its people and how lucky I am to be in ... the half of the American population that gets the best treatment in the world. Because ultimately there's the rub. What about the other half?' (Sellers 2014).

\section{Discussion and conclusion}

This research, firstly, shows health journalism can be analysed using international lesson-drawing. Referencing Bale (2005) and Klein (1997), our hypothesis, testing RQ1, was confirmed - the majority of lesson-drawing commentary uncovered here was negative. While more coverage overall referred to Canadian Medicare, the NHS was also regularly posited as a flawed single-payer model. Commentators, particularly in the most conservative 'business-friendly' print media, exposed what they saw as deficiencies in another country's policies, to, if not 'provoke horror' (Klein 1997, p. 1271), then at least generate antipathy. 
Moreover, we found that Republican-oriented titles consistently highlighted NHS flaws. When this was linked with Obamacare, editorial and opinion writers reflected domestic political motivation. Democrat newspapers' opinion was less hostile, but not universally so, where the relative autonomy of syndicated columnists was a factor (Duff 2008, p. 240).

Whether hostility from the most prominent conservative business titles is linked to ownership can be debated. Initial research saw little shift in health news at The Wall Street Journal after News Corp purchased the right-leaning outlet (Bedingfield 2012). Nevertheless, later studies emphasised a surge in general political content and an editorial tone shift following the acquisition (Archer and Clinton 2018; Wagner and Collins 2014). The Investor's Business Daily was founded by William O'Neil (Alpert 2016) and operates as one of the O'Neil family of investment companies. It offers an example of a title founded before the 2008 crash that has had a particular business interest: to "fill the information gap ... [between] the individual investor and [the] business community' (Garcia 2021). One assessment found the title has shown an attachment towards 'conservative causes through story selection and/or political affiliation' on environmental issues (Anon 2020). While another appears to find state education treated negatively (Bracey 1999). The coverage of health, we have seen, fits these patterns.

Second, given that a sizeable slice of the negative lesson-drawing came from the business press, this supplements research showing that, alongside business journalism as a whole (Tambini 2010; Butterick 2015), opinion and editorial prioritises investor interests. These papers' selection appears to show a coverage that tended to favour arguments opposing the NHS model over, for instance, broader consumer interests in a lower-cost service, as discussed below. NHS delivery does not, of course, require private investors and it provides primarily, not-for-profit, state delivery. However, US companies have been encouraged and commissioned to deliver some services (Lister 2013).

Third, carrying out this rarely performed experiment in analysing one country's reporting of another state's social policy illuminates how claims of flaws were justified. We can see journalistic rituals played out—some within an intermedia framework. US editorial and commentary drew lessons while intermittently sourcing UK news (Table 1). In exploiting the linguistic tie, US leader writers' selection of accessible UK sources (Marques and Mont'Alverne 2019) was facilitated by the UK media's news values, with its regular focus on negative news and sensational or unusual events concerning the NHS.

It was often in the business press that the breadth of international comparative data was displayed, regularly in an engaging and intelligent form. Therefore, to assess RQ2 and the themes framed, it is worthwhile considering whether any less newsworthy UK data, placing the NHS above US healthcare, were downplayed here (van der Meer et al. 2019).

Two riders apply. If UK health outcomes surpass US results that could be because health determinants, such as employment rights, income inequality, obesity and homicide rates, differ (see Avendano and Kawachi 2014). While since 2010 UK demand from an ageing population has increased, alongside funding cuts and staff shortages (Watkins et al. 2017). 
Given these considerations, it is important to analyse the contextual data that was played down, thus, supporting negative lessons (RQ1). Regarding the framing on care, some commentators drew negative lessons by justifiably focusing on poorer UK cancer care. Nevertheless, both countries' survival rates for breast cancer were above the OECD average by 2014 (OECD 2017, p. 123). And while older people with cancer in the US, covered by single-payer Medicare, had better outcomes, younger people with chronic diseases fared worse (Desai et al. 2010).

There was reference to NHS 'death panels'. Yet fewer journalists compared, or even mentioned, data on life expectancy. Newspaper coverage suggesting the UK did not perform so well on life-saving interventions was justified (Dayan et al. 2018). Nonetheless, according to the World Health Organization, in 2016, UK life expectancy at birth was nearly three years higher than in the US (81.4 years, as opposed to 78.5) (2018). For 'healthy life expectancy', the gap was longer (71.9 years versus 68.5) (WHO 2018; Dayan et al. 2018).

When drawing lessons on health administration, a handful portrayed the NHS as a controversial oddity, where the numbers employed were ranked with the Chinese Red Army. However, fewer commentators focused on costs, with a minority, only one a business journalist, negatively framing their work around the truism that the US was the outlier. It spent more than twice as much per person on healthcare than the UK and around five times as much on administration overall (Pritchard and Wallace 2011; Gulland 2017), making the UK system among the most efficient in reducing mortality rates and the US the least (Dayan et al. 2018).

We found that some US media assumptions about lesson-drawing from the UK were predicated on the negative framing of rationing, including waiting times and funding. Columnists may well be correct that United States waiting times are shorter (Sowell 2009). But one international survey of A\&E waiting times found that fewer US patients reported themselves as being treated in under four hours than in the UK. The OECD suggested that among developed countries, 'the NHS's performance on waiting times for selected procedures ... is generally around the average' (Dayan et al. 2018, pp. 23-25, 39; see also OECD 2017). This questions the view of some that 'once health care is a "free good"' 'soaring demand and overuse' (Anon 2009b) will ensue, with its attendant pressure on waiting times. Rationing and NICE was another frame for lesson-drawing, with the editorial value of conflict. Yet comparable access to US healthcare was not always spelt out in order to recognise US healthcare rations for the uninsured (OECD 2017; Dayan et al. 2018).

Fourthly, such alternative evidence could point to one less-addressed conundrum in US coverage-why the UK public, and politicians of nearly all stripes, profess affection for the NHS. Indeed, faced with an increasing volume of stories from 2011 detailing the NHS's financial difficulties (Robertson et al. 2017, p. 23), polling suggests most UK residents demanded increased investment (Appleby et al. 2019). 
Instead, the lesson regularly drawn by the senior staff in editorial and opinion was that the UK body politic was the outsider. ${ }^{2}$ The UK Conservative policy of squeezing funds and seeking 'efficiency savings' was distorted (Park et al. 2014, p. 401) to become the logic of an outlier model-'socialized medicine' - rather than a political choice to not fund at previous levels. Rightist US commentary did not typically claim that ostensibly 'necessary' austerity measures stemming from previous 'overspending' was the key issue (in line with the prevailing UK right-of-centre narrative). Nor even was it prominently stated who the actors performing the 'socialized' rationing were, namely Conservative-dominated governments since 2011. It was instead presented as the logic of the oddity - universal healthcare - to ration to 'devastating and cruel' levels (Anon 2011).

Again, regarding intermedia editorial and news values (Table 1), the tragic case of a former NHS director dying after waiting for an operation at her own hospital (Anon 2011) exemplifies the UK news value of the sensational. That a US leader writer sourced a UK newspaper report of this in a subsequent editorial might suggest its editorial worthiness includes this unusualness, going beyond the findings of Marques and Mont'Alverne (2019). But instead, it appears to replicate the scholars' classification, as it is transformed to another of their editorial values - conflict. It is used here to represent a norm, providing proof, as the same editorial put it that the NHS 'has followed the path that all socialist systems must follow: It is breaking under its own weight' (Anon 2011).

Fifth, to consider habitus and field theory, among the minority who wrote positively about the NHS, it was noticeable that a number had UK local knowledge and direct experience of 'the UK mindset' regarding NHS healthcare. They were also, typically, outsiders in this context-not health columnists, nor part of the papers' opinion and editorial senior sanctum, and, thus, less likely to have such an impact on day-to-day judgements of editorial worthiness (Table 1) (Firmstone 2019, pp. 3, 16; Duff 2008, p. 232).

Overall, we see a focus on flaws, with less convenient evidence explained away (H1). Critics of the NHS could see US writers as illuminating a collective UK selfharming delusion and addiction to the NHS 'fix' (but also as a system where investor opportunities lie (Lister 2013)). Yet, US coverage of socialised rationing can also be seen as ahistorical, by failing to differentiate between when spending reduced waiting lists and when politically motivated cost cutting increased waiting times (Anandaciva and Thompson 2017). Such a consideration, often identified by a distant editorial elite, not only may well reflect the newspapers' ideological alignment, but also contrasts with positive local UK context and perception (Zeng 2018). Moreover, rationing and 'death panels' were often portrayed as part of a process characterised by soaring overuse and bulging bureaucracy, leading to ballooning costs. But this description neglects to fully

\footnotetext{
${ }^{2}$ For one editorial, it was the UK mind that was at fault. It attempted to explain what it admitted was the NHS's enduring popularity and that it is 'entrenched in the fabric of national life'. But that, in the language of othering, US readers were told, was 'because once hooked, a heroin addict demands his heroin' (Anon. 2013b).
} 
appreciate a key transatlantic healthcare contrast. The costs of UK healthcare have been far less than those in the US-and administration costs lower still.

\section{References}

Alpert, L., 2016. Investor's Business Daily Will Become a Weekly. [online] Wall Street Journal. https:// www.wsj.com/articles/investors-business-daily-will-become-a-weekly-1457131255. Accessed Dec $21,2019$.

Anandaciva, S. and Thompson, J., 2017. What is happening to waiting times in the NHS? [online] The King's Fund. https://www.kingsfund.org.uk/publications/articles/nhs-waiting-times. Accessed Jun $20,2019$.

Anon. 2009a. How house bill runs over grandma. Investor's Business Daily. 3 Aug.

Anon. 2009b. Why the elderly are right to worry when the government rations medical care. Wall Street Journal. 13 Aug.

Anon. 2010a. Coming to a hospital near you? Investor's Business Daily, ISSUES \& I, 6 Feb.

Anon. 2010b. Redistributing health? Investor's Business Daily. 17 May.

Anon. 2010c. Regulated to death by ObamaCare? Investor's Business Daily, 28 Dec, p. A12.

Anon. 2011. Pain and suffering. Investor's Business Daily, ISSUES \& I, 7 Apr., p. A12.

Anon. 2013a. It can happen here. Investor's Business Daily. 14 Feb.

Anon. 2013b. Obamacare in wonderland. Investor's Business Daily, A, p. A18.

Anon. 2020. Investors Business Daily - Media Bias/Fact Check. [online] <https://mediabiasfactcheck. com/investors-business-daily/. Accessed Mar 31, 2020.

Appleby, J., N. Hemmings, D. Maguire, J. Morris, L. Schlepper and D. Wellings. 2019. Public satisfaction with the NHS and social care in 2018: Results from the British Social Attitudes survey. Nuffield Trust and the King's Fund.

Archer, A.M., and J. Clinton. 2018. Changing owners, changing content: Does who owns the news matter for the news? Political Communication 35 (3): 353-370.

Avendano, M., and I. Kawachi. 2014. Why do Americans have shorter life expectancy and worse health than do people in other high-income countries? Annual Review of Public Health 35 (1): 307-325.

Bale, T. 2005. 'It's Labour, but not as we know it.' Media lesson-drawing and the disciplining of social democracy: A case study. British Journal of Politics and International Relations 7 (3): 386-401.

Bedingfield, S. 2012. Journal's health care plan coverage free of Murdock's conservative bias. Newspaper Research Journal 33 (2): 68.

Bednarek, M., and H. Caple. 2012. News discourse. London: Bloomsbury.

Begley, S. 2009. The top 5 lies about Obama's health care reform. [online] Newsweek. http://www. newsweek.com/top-5-lies-about-obamas-health-care-reform-78895. Accessed Mar 5, 2018.

Boesman, J., A. Berbers, L. D'Haenens, and B. Van Gorp. 2017. The news is in the frame. Journalism 18 (3): 298-316

Boykoff, M.T. 2008. The cultural politics of climate change discourse in UK tabloids. Political Geography 27 (5): 549-569.

Bracey, G.W. 1999. A tale of two studies. Phi Delta Kappan 80: 10.

BurrellesLuce. 2013. Top media outlets: Newspapers, blogs, consumer magazines, broadcasters, websites \& social networks. [online]. http://www.burrellesluce.com/sites/default/files/Top_Media_June_ 2013_FNL(1).pdf.

Butterick, K.J. 2015. Complacency and collusion. London: Pluto Press.

Callahan, D. 2011. Rationing: Theory, politics, and passions. Hastings Center Report 41 (2): $23-27$.

Caple, H. and M. Bednarek. 2013. Delving into the Discourse: Approaches to News Values in Journalism Studies and Beyond. Reuters Institute for the Study of Journalism, (December), pp. 1-29.

Cashin, C. and A. El-Sayed. 2020. Webinar: 2020 US Elections-Healthcare During a Pandemic. [online] www.chathamhouse.org. Accessed Dec 28, 2020.

Castle, S. 2016. Junior doctors' strike in England disrupts care for thousands. The New York Times. 16 Jan.

Chomsky, D. 2006. 'An interested reader': Measuring ownership control at The New York Times. Critical Studies in Media Communication 23 (1): 1-18. 
Davis, E.R., R. Wilson, and B. Dalton. 2018. Another slice of PISA: An interrogation of educational cross-national attraction in Australia, Finland, Japan, and South Korea. Compare. https://doi.org/10. 1080/03057925.2018.1510305.

Dayan, M., D. Ward, T. Gardner, and E. Kelly. 2018. How good is the NHS? The Nuffield Trust. [online]. www.soapbox.co.uk.

Desai, M., B. Rachet, M.P. Coleman, and M. McKee. 2010. Two countries divided by a common language. Journal of the Royal Society of Medicine 103 (7): 283-287.

Draper, R. 2019. How 'Medicare for All' went mainstream. The New York Times. 17 Aug.

Duff, A.S. 2008. Powers in the land? Journalism Practice 2 (2): 230-244.

Dyer, G., 2018. Universal health care is a no-brainer. Pittsburgh Post-Gazette. 9 Feb.

Entman, R.M. 1993. Framing: Toward clarification of a fractured paradigm. Journal of Communication 43 (4): 51-58.

Firmstone, J. 2008. The editorial production process and editorial values as influences on the opinions of the British press towards Europe. Journalism Practice 2 (2): 212-229.

Firmstone, J. 2019. Editorial journalism and newspapers' editorial opinions. In: Oxford research encyclopedia of communication. Oxford: Oxford University Press.

Freelon, D.G. 2010. ReCal: Intercoder reliability calculation as a web service. International Journal of Internet Science 5 (1): 20-33.

Glied, S. 2009. Single payer as a financing mechanism. Journal of Health Politics, Policy and Law 34: 593.

Goodnough, A. 2019. Democratic Debate Turns Ferocious Over Health Care. The New York Times. 30 Jul.

Gulland, A. 2017. UK has best health system in developed world, US analysis concludes. BMJ (Clinical research ed.) 358: j3442.

Gusmano, M.K. 2012. Health care reform. In: The Obama presidency: A preliminary assessment. New York: State University of New York Press.

Haeder, S.F. 2020. 7 things President-elect Biden can achieve on health care. [online] The Conversatiion. https://theconversation.com/7-things-president-elect-biden-can-achieve-on-health-care-149798. Accessed Dec 28, 2020.

Hallin, D.C., M. Brandt, and C.L. Briggs. 2013. Biomedicalization and the public sphere: Newspaper coverage of health and medicine, 1960s-2000s. Social Science \& Medicine 96: 121-128.

Hansen, A., and D. Machin. 2013. Media \& communication research methods. Basingstoke: Palgrave Macmillan.

Hockett, R.C. 2010. Making sense of the health care reform debate. Cornell Law Faculty Publications. Paper, [online] 43. http://scholarship.law.cornell.edu/facpub. Accessed Mar 5, 2018.

Illical, M., and K. Harrison. 2007. Protecting endangered species in the US and Canada: The role of negative lesson drawing. Canadian Journal of Political Science 40 (2): 367-394.

Jones, B. 2020. More Americans now favor single payer health coverage than in 2019। Pew Research Center. [online]. https://www.pewresearch.org/fact-tank/2020/09/29/increasing-share-of-americans-favor-a-single-government-program-to-provide-health-care-coverage/. Accessed Feb 21, 2021.

Kirzinger, A., A. Kearney, and M. Brodie. 2020. KFF Health Tracking Poll-February 2020: Health Care in the 2020 Election. [online] Kaiser Family Foundation. https://www.kff.org/health-reform/poll-finding/ kff-health-tracking-poll-february-2020/. Accessed Dec 28, 2020.

Klein, R. 1997. Learning from others. Journal of Health Politics, Policy and Law 22 (5): 1267-1278.

Krause, M. 2011. Reporting and the transformations of the journalistic field: US news media, 1890-2000. Media, Culture and Society 33 (1): 89-104.

Lister, J. 2013. Health policy reform. Faringdon: Libri.

Liu, J.L., and R.H. Brook. 2017. What is single-payer health care? Journal of General Internal Medicine 32 (7): 822-831.

Mariner, W.K. 2014. Allocating responsibility for health care decisions under the United States Affordable Care Act. Revista Portuguesa de Saúde Pública 32 (2): 144-150.

Marques, F.P.J. and C. Mont'Alverne. 2019. What are newspaper editorials interested in? Understanding the idea of criteria of editorial-worthiness. Journalism.

Mayring, P. 2014. Qualitative content analysis: theoretical foundation, basic procedures and software solution. [online] Social Science Open Access Repository. http://sgo.sagepub.com/content/4/1/2158244014 522633.short.

McKnight, D. 2010. Rupert Murdoch's News Corporation: A media institution with a mission. Historical Journal of Film, Radio and Television 30 (3): 303-316. https://doi.org/10.1080/01439685.2010.505021.

McKnight, D. 2012. Rupert Murdoch: An investigation of political power. Sydney: Allen \& Unwin. 
van der Meer, T.G.L.A., A.C. Kroon, P. Verhoeven, and J. Jonkman. 2019. Mediatization and the disproportionate attention to negative news. Journalism Studies 20 (6): 783-803.

Meirick, P.C. 2013. Motivated misperception? Party, education, partisan news, and belief in 'death panels.' Journalism and Mass Communication Quarterly 90 (1): 39-57.

Myers, D. 2017. US healthcare: A ‘disaster' of a system. Pitt Political Review 12 (1): 16-19.

Neville, S. 2019. Could the NHS be part of a US-UK trade deal? Financial Times.

Nossal, K. 2018. The Kin-Country Thesis Revisited. In: D. Orsi, ed. The 'Clash of Civilizations' 25 Years on a Multidisciplinary Appraisal. E-International Relations.

Nutley, S., J. Downe, S. Martin, and C. Grace. 2012. Policy transfer and convergence within the UK. Policy and Politics 40 (2): 193-209.

Oberlander, J. 2003. The politics of health reform. Health Affairs.

OECD. 2017. Health at a Glance 2017. Health at a Glance. [online] OECD Publishing. http://www.oecdilibrary.org/social-issues-migration-health/health-at-a-glance-2017_health_glance-2017-en. Accessed Aug 24, 2018.

Park, C., M. Wilding, and C. Chung. 2014. The importance of feedback: Policy transfer, translation and the role of communication. Policy Studies 35 (4): 397-412.

Pickard, V. 2020. Democracy without journalism? Oxford: Oxford University Press.

Pritchard, C., and M.S. Wallace. 2011. Comparing the USA, UK and 17 Western countries' efficiency and effectiveness in reducing mortality. JRSM Short Report 2 (60): 1-10.

Robertson, R., L. Wenzel, J. Thompson, and A. Charles. 2017. Understanding NHS financial pressures: How are they affecting patient care? The King's Fund, [online] (March), pp. 1-126. https://www.kings fund.org.uk/sites/default/files/field/field_publication_file/Understanding NHS financial pressures - full report.pdf.

Saraisky, N.G. 2015. Analyzing public discourse: Using media content analysis to understand the policy process. Current Issues in Comparative Education 18 (1): 26-41.

Schultz, I. 2007. The journalistic gut feeling: Journalistic doxa, news habitus and orthodox news values. Journalism Practice 1 (2): 190-207.

Sellers, F.S. 2014. Sticker shock. The Washington Post. 25 Mar.

Soloski, J. 2019. The murky ownership of the journalistic enterprise. Journalism 20 (1): 159-162.

Sowell, T. 2009. Thomas Sowell on economics of medical care. Investor's Business Daily. 28 Oct.

Stone, D. 1999. Learning lessons and transferring policy across time, space and disciplines. Politics 19 (1): 51-59.

Stones, R. 2015. Why current affairs needs social theory. London: Bloomsbury Academic.

Takayama, K., F. Waldow, and Y.K. Sung. 2013. Finland has it all? Examining the media accentuation of 'Finnish Education' in Australia, Germany and South Korea. Research in Comparative and International Education 8 (3): 307-325.

Tambini, D. 2010. What are financial journalists for? Journalism Studies 11 (2): 158-174.

The Patient Protection and Affordable Care Act. Public Law 111-148 111th Congress.

Thomas, C. 2009. A disturbing look at socialized medicine. Chicago Daily Herald. 19 Aug.

Tunney, S. 2007. Labour and the press. Eastbourne: Sussex Academic Press.

Veltman, N. 2016. Data on newspaper presidential endorsements. [online]. https://github.com/veltman/endor sements/. Accessed Aug 14, 2019.

Wagner, M.W., and T.P. Collins. 2014. Does ownership matter? Journalism Practice 8 (6): 758-771.

Watkins, J., W. Wulaningsih, C. Da Zhou, D.C. Marshall, G.D.C. Sylianteng, P.G. Dela Rosa, V.A. Miguel, R. Raine, L.P. King, and M. Maruthappu. 2017. Effects of health and social care spending constraints on mortality in England. British Medical Journal Open 7 (11): e017722.

WHO. 2018. Monitoring Health for the SDGs. Geneva: World Health Organization.

Wilson, P.M., A.M. Booth, A. Eastwood, and I.S. Watt. 2008. Deconstructing media coverage of trastuzumab (Herceptin). Journal of the Royal Society of Medicine 101 (3): 125-132.

$\mathrm{Xu}$, R. 2017. Collective identity, Anglo-Saxon bond and the persistence of the Anglo-American special relationship. European Journal of Interdisciplinary Studies. 3. EUSER: 122.

Yeginsu, C. 2018. Is Trump correct that the U.K.'s National Health Service is 'not working'? The New York Times. 6 Feb.

Zeng, Y., 2018. Morphology and typology of China correspondents: A habitus-based approach. Journalism.

Publisher's Note Springer Nature remains neutral with regard to jurisdictional claims in published maps and institutional affiliations. 
Sean Tunney is a Principal Lecturer in Journalism at the University of Roehampton. His research interests include health communications, business journalism and the politics of media policymakers in the UK.

Jane Thomas is a Senior Lecturer in Public Health at the University of Brighton. She is a Fellow of the UK Faculty of Public Health. Her research interests include accountability and public involvement in issues influencing health.

Adam Cox is a Senior Lecturer in Journalism at the University of Roehampton. His current research is focused on financial policymakers and the media's role in agenda building. 